\title{
SANDSTONE GEOMORPHOLOGY OF SOUTH-WEST JORDAN, MIDDLE EAST
}

\author{
Piotr Migońn ${ }^{1}$, Andrew Goudie ${ }^{2}$ \\ ${ }^{1}$ Department of Geography and Regional Development, University of Wrocław, Poland \\ ${ }^{2}$ School of Geography and the Environment, University of Oxford, Oxford, Great Britain
}

Manuscript received: May 31, 2014

Revised version: July 25, 2014

\begin{abstract}
Migó́ P., Goudie A. 2014. Sandstone geomorphology of South-West Jordan, Middle East. Quaestiones Geographicae 33(3), Bogucki Wydawnictwo Naukowe, Poznań, pp. 123-130, 5 figs. DOI 10.2478/quageo-2014-0035, ISSN 0137-477X.

ABSTRACT: In the desert environment of south-west Jordan thick sequences of continental sandstones of Cambrian-Ordovician age support spectacular scenery, comparable with that of the Colorado Plateau of south-west USA or the central Sahara and similar in many aspects to the Danxia landform of southern China. Dissection of a sandstone tableland has given rise to numerous inselbergs and large mesas, rising from the sand-covered desert floor. The height of the hills varies from a few tens to 500-700 $\mathrm{m}$ in the Wadi Rum area, whereas their slope shapes are controlled by lithological properties of particular sandstone units. Rock walls of the sandstone inselbergs are subject to frequent rock falls and rock slides and host an impressive array of tafoni and honeycombs due to selective weathering, as well as a number of rock arches. Lithological differences within the sandstone sequence are crucial controls on the shape and evolution of rock slopes, exerting the influence via contrasting patterns of weathering and slope failures. The presence of ferruginous layers in the Umm 'Ishrin Sandstone is of major importance and explains the fundamental morphological differences between the otherwise similar Umm 'Ishrin and Disi sandstone units.
\end{abstract}

KEY WORDS: sandstone, hillslope evolution, desert environments, Jordan

Address of the corresponding author: Piotr Migon, Department of Geography and Regional Development, University of Wroctaw, Pl. Uniwersytecki 1, 50-137Wroctaw, Poland; e-mail: piotr.migon@uni.wroc.pl

\section{Introduction}

Some of the most spectacular rock landscapes in the world are supported by consolidated clastic deposits of ancient sedimentary basins, mainly sandstones and conglomerates. A repetitive geomorphic theme in these areas is an array of dissected tablelands and flat-topped mesas bounded by precipitous cliffs, along with a range of spectacular minor features, including pinnacles, joint-aligned clefts, bedding caves and massive boulder talus. Perhaps the best known examples of such landscapes are those in southwest USA, within the Colorado Plateau, but their distribution is truly global (Young et al. 2009), with major examples occurring, for example in South Africa (Grab et al. 2011) or in the northern territories of Australia (Young 1987, Grimes et al. 2008). While these assemblages of rock-controlled landforms are often linked with desert environments, they are by no means confined to arid or semi-arid lands. In humid central Europe, extensive tracts of sandstone plateaus and escarpments with various degrees of dissection occur in the northern part of the Bohemian Massif, mainly in the Czech Republic (Adamovič et al. 2006), but extending into adjacent parts of Germany (Rast 1959) and Poland (Kasprzak, Migon 2014). Likewise, in the cold and humid Britain one can find examples of sandstone landforms strikingly similar to those 
known from much warmer and drier terrains (Robinson, Williams 1994). In China, the term 'Danxia Landform' has long been used to emphasize the specific nature of sedimentary terrains and is defined as 'landform made up of non-marine red clastic rock and characterized by red walls and red cliffs' (Peng Hua 2000, p. 8). The presence of cliffed slopes is considered essential (Zhao Xun 2009, p.107) and great emphasis is put on rounding of upper cliffs, which distinguishes Danxia landform from other rock terrains in sedimentary rocks (Huang Jin 2009, p. 133).

In this research note we will focus on the geomorphology of a spectacular sandstone terrain in the arid environment of south-west Jordan, exploring relationships between slope shape and geological structure and outlining its geomorphic evolution. While doing so, we hope to extend the basis for comparative geomorphological analysis of sandstone and conglomerate terrains worldwide which, despite significant advances made in recent years, remain under-researched, especially in contrast with landscapes developed in other common rock types such as limestone and granite (Young et al. 2009). This paper builds upon previous publications (Goudie et al. 2002, Migoń et al. 2005), but looks more closely into how the diversity of sandstone itself influences morphological differences within the area which may be considered uniform in terms of climate and tectonic setting.

\section{Geographical setting}

The sandstone terrain of south-west Jordan referred to in this paper occurs to the north-west of the coastal city of Aqaba, beyond the Dead Sea Transform and the mountains of Edom, and occupies a triangular area bounded by the outcrops of crystalline basement rocks in the west, $\mathrm{R}^{\prime}$ as an Naqb escarpment in the north-east and the Saudi Arabian border in the south (Fig. 1). The best known locality within its boundaries is Wadi Rum, recently (2011) inscribed as a World Heritage property, but sandstone outcrops occupy a much larger terrain, extending into the territory of Saudi Arabia. The altitude rises from c. 1000 m a.s.l. in the sand-covered plains to $1754 \mathrm{~m}$ a.s.l. in Jebel Rum, the highest sandstone massif in the

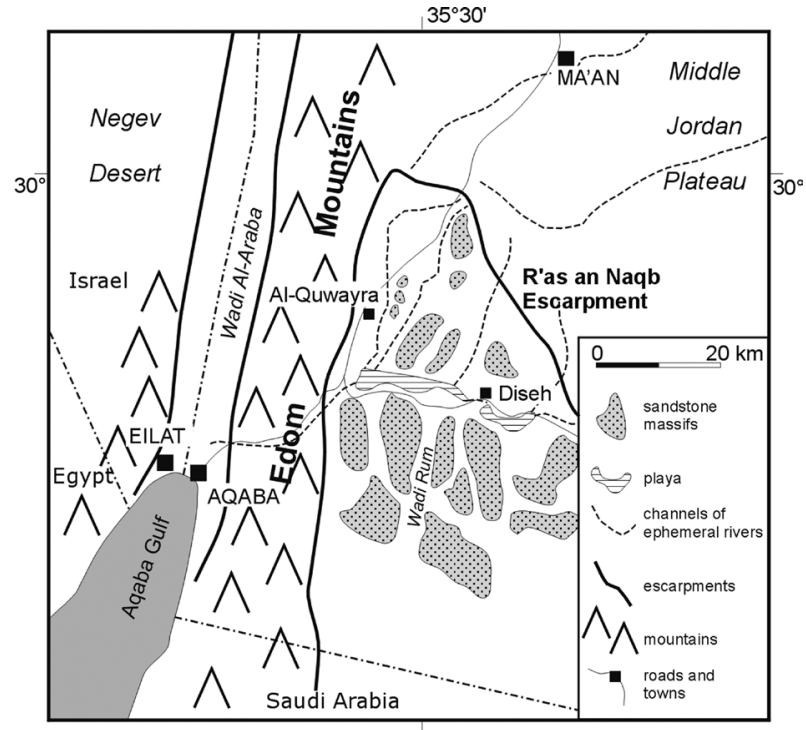

Fig. 1. Location of the sandstone terrain in south-west Jordan

area. Thus, altitudinal differences are extreme over short distances and many sandstone cliffs are nearly vertical.

The prominent mountains of Edom act as an effective orographic barrier for the occasional advection of moist air masses travelling from the west, and the entire sandstone area lies in a rain shadow. Therefore, the climate of the area is arid, with mean annual precipitation within the range of 40-60 $\mathrm{mm}$ and diminishing eastwards. The bulk of this precipitation falls between December and April, more than $90 \%$ of it in the form of storms of short duration. Runoff is produced five to seven times a year. Mean monthly temperatures range from $11^{\circ} \mathrm{C}$ in January to $28^{\circ} \mathrm{C}$ in July, with absolute maxima above $45^{\circ} \mathrm{C}$ and absolute minima down to $+2^{\circ} \mathrm{C}$ (Abu-Safat 1987). Frost days are only 6-8 per year (Abu-Safat 1987), hence frost weathering is effectively absent. Consequently, vegetation is sparse and restricted to a few major species of shrubs and grasses. Thus, the landscape is typical of a desert, with little soil and with bedrock surfaces widely exposed (Fig. 2).

Despite aridity, the area is inhabited and agriculture is locally developed, based on abundant groundwater from sandstone aquifers. The main towns include Al-Quwayra on the main Amman - Aquaba road and Diseh in the eastern part, whereas the main tourist destination is the Bedouin settlement in the Wadi Rum area, from which desert tours are organized. 


\section{Landform diversity and its relationship to geology}

\section{Geology}

The sandstones of south-west Jordan belong to the Ram Sandstone Group (RSG) and are of early Palaeozoic age. Their deposition is considered to be a result of the uplift of the Arabian-Nubian Craton, which produced mountains from which an enormous thickness of siliciclastics was eroded and deposited in inland basin areas, on erosionally truncated parts of basement terrain (Selley 1972, Makhlouf, Abed 1991, Amireh 1994). The RSG is divided into four major units, named in decreasing order of ages as Salib Arkose, Umm 'Ishrin Sandstone, Disi Sandstone, and Umm Sahm Sandstone (Abdelhamid 1990, Rabba 1991). The former three are of Cambrian age, the latter one is Ordovician, although the uppermost part of the Disi is probably Ordovician too. The rather thin Salib Arkose plays a minor role in shaping the landscape of the area, whereas among the other three each supports a distinctive morphology. Since the dip of consecutive sandstone units is to the east/north-east, progressively younger rocks are exposed in the north-east direction.

The Umm 'Ishrin Sandstone is a brownish-red, medium- to coarse-grained, poorly cemented sediment, consisting predominantly of quartz which makes up to $95 \%$ of the rock. It is of fluvial origin, hence large-scale trough cross-bedding is common. Locally it contains highly ferruginous layers from a few to a few tens of centimetres thick, as well as insets of pebbly conglomerates (Abdelhamid 1991, Makhlouf, Abed 1991). Moreover, towards the top of the unit there occur beds of whitish sandstone of a few tens of metres thick, superficially similar to the overlying Disi Sandstone. The cumulative thickness of the Umm 'Ishrin Sandstone is $315 \mathrm{~m}$. The Disi Sandstone is a whitish grey to pure white sandstone with scattered quartz granules and pebbles. It is predominantly medium-grained, although generally finer than the Umm 'Ishrin Sandstone. Its sedimentary environment was that of a braided river system, therefore large-scale planar and trough cross-bedding dominate. The thickness of Disi Sandstone comes to $265 \mathrm{~m}$. The Umm Sahm
Sandstone is typified by alternating thin beds of sandstone and mudstone. Dense jointing results in disintegration of the Umm Sahm unit into angular rock fragments, unknown in the Disi Sandstone and limited to iron-rich layers in the Umm ‘Ishrin Sandstone (Migoń et al. 2005).

\section{Landform diversity}

Geomorphological diversity of the sandstone terrain can be usefully discussed considering two spatial scales, regional and local. At the regional scale, the area represents a large basin surrounded by higher ground, particularly from the west and north-east. However, summit surfaces of the highest residual massifs rise above the mean altitude of the adjacent uplands, suggesting a major relief inversion. The basin floor is dotted with numerous residual hills of varied size, height, and outline. In the north, relatively low inselbergs dominate, 50-200 m high, and much isolated from their neighbours, although clusters do occur. Towards the south, the spacing of residual massifs diminishes, whereas their height increases up to $500-700 \mathrm{~m}$. Here, it is no longer appropriate to speak about sandstone inselbergs, as their separating corridors are long and narrow. Further to the east, individual massifs converge into a plateau, underlain mainly by the Umm Sahm Sandstone unit and incised by a system of wadis. Osborn (1985) suggested that this variability has resulted from headward erosion and dissection of the once coherent sandstone upland, followed by scarp retreat of sandstone rock slopes. The greatest loss of mass occurred in the north-western part, in proximity to the major fluvial system draining to the Gulf of Aqaba, and is consistent with the above hypothesis. If Osborn's (1985) hypothesis is accepted, then a sequential development of sandstone terrain may be envisaged, from initial dissection, through the development of corridors (defiles) between upland remnants, which later turn into isolated inselbergs. The final stage is a plain cut across sandstone, with occasional residual hills, or an exhumed basement erosional surface. However, lithological differences between sandstone beds modify these general relationships and account for considerable local variability and dissimilar evolutionary ways of rock slopes. 


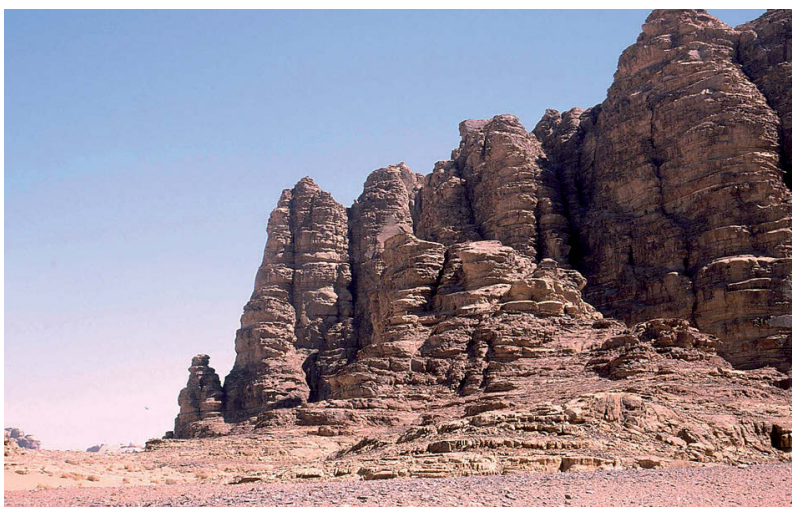

Fig. 2a. Example of sandstone rock slopes in south-west Jordan: angular rock slopes in the Umm 'Ishrin sandstone, the northern sector of Wadi Rum area

The differences between typical slope forms developed in the Umm 'Ishrin, Disi, and Umm Sahm Sandstones become obvious even to the casual observer. The Umm 'Ishrin landscape is dominated by vertical rock slopes, towers and spires with vertical walls, locally benched (Fig. 2a), whilst the Disi usually produces rounded forms of bell-shaped hills, domes or low whalebacks (Fig. 2c). Young et al. (2009) distinguish between two fundamental slope forms within sandstone relief, vertical cliffs and curved slopes respectively, and this is exactly what occurs in the study area. A further difference results from the intensity of cavernous weathering present on rock slopes within each unit. It is ubiquitous within the Umm 'Ishrin Sandstone, hence deep niches and networks of tafoni are very common and the slopes resemble giant honeycombs (Fig. 2b) (Abu-Safat 1987, Goudie et al. 2002). Within the Disi sandstones, cavernous weathering is much more restricted and larger caverns are few

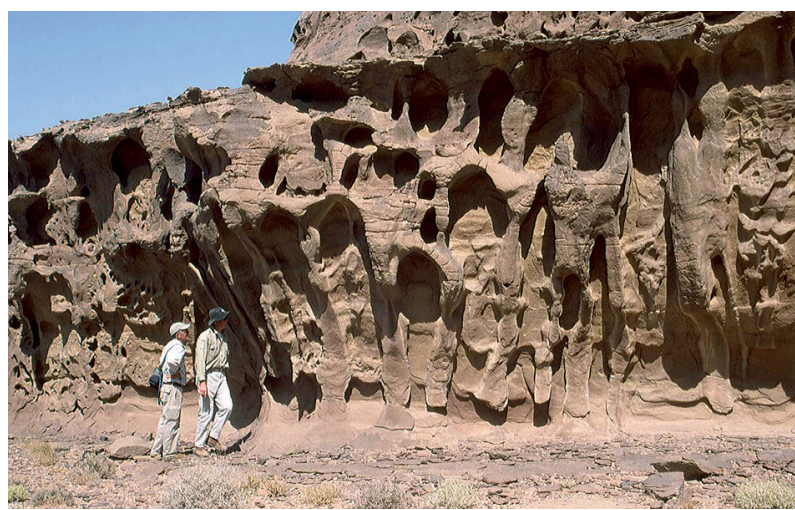

Fig. 2b. Example of sandstone rock slopes in south-west Jordan: extensive cavernous weathering within the Umm 'Ishrin sandstone

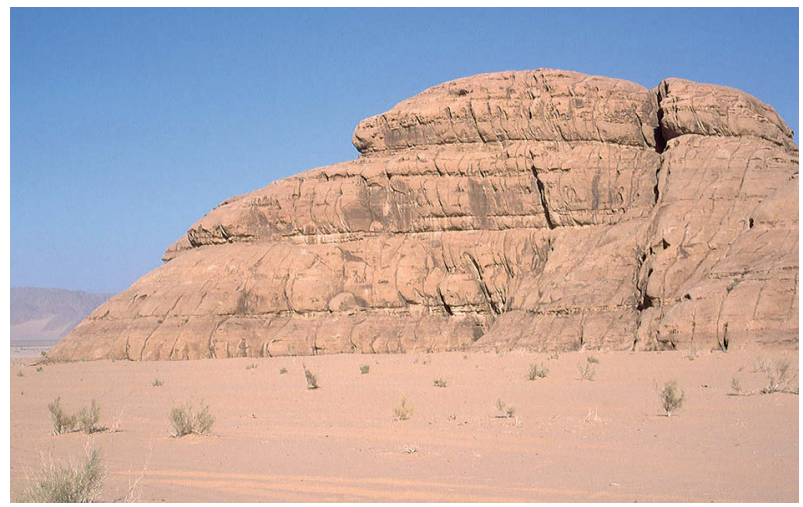

Fig. 2c. Example of sandstone rock slopes in south-west Jordan: rounded slopes of an inselberg built of the Disi sandstone, near Diseh

and far apart. Instead, the curved slopes of the Disi have smooth surfaces and mid-slope benches are rare. A notable feature observed within the Disi Sandstone are natural rock arches, among which those at Jebel Al Kharaz east of Al-Quwayra are particularly impressive (Fig. 2d). Altogether, around ten examples are known in the area, and the spans of the largest of them exceed 25 $\mathrm{m}$, with the height up to $10-15 \mathrm{~m}$ (and $35 \mathrm{~m}$ in the extreme example of Burdah rock bridge) (Debossens 2000). Slopes developed in the Umm Sahm Sandstone have a different appearance and lack in long sections of vertical cliffs. Instead, they consist of a moderately inclined $\left(40-60^{\circ}\right)$, dissected rock slope above and a long debris slope at the angle of repose below (Fig. 2e). Cavernous weathering is largely absent, apparently because of the uniformity of the rock and dense jointing which contributes to efficient rock breakdown and high detachment rate. Hence, surface

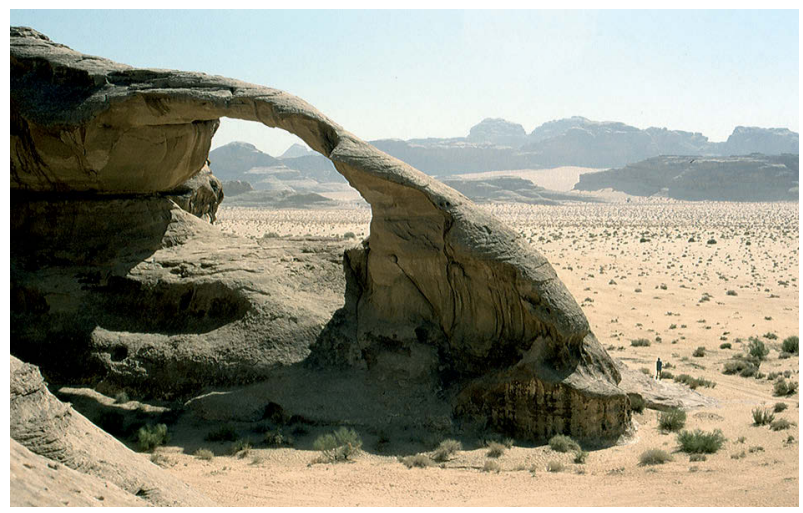

Fig. 2d. Example of sandstone rock slopes in south-west Jordan: one of the rock arches in the Jebel Al Kharaz massif built of the Disi sandstone 


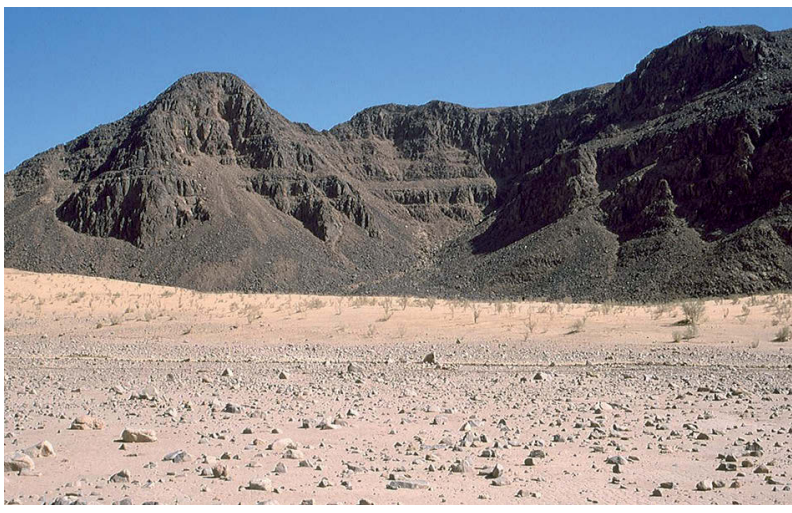

Fig. 2e. Example of sandstone rock slopes in south-west Jordan: rock and debris slope in the Umm Sahm sandstone, east of town of Diseh

stability is insufficient to allow for the growth of caverns inside the rock faces.

A typical Umm 'Ishrin Sandstone slope (Fig. 2a) consists of a case hardened red cliff towering above its base by a few tens to a few hundreds of meters, which usually terminates at a distinct piedmont angle, although a rock-cut ramp inclined by $30-40^{\circ}$ is occasionally present. The rock slope in its lower segment may be hidden beneath talus which extends from the cliff away towards the adjacent plain, or locally by climbing dunes. If talus and aeolian sand are absent, overhangs are frequently observed and some attain enormous dimensions, of $50 \mathrm{~m}$ across, 10-15 $\mathrm{m}$ deep and up to $10 \mathrm{~m}$ high. Overhangs (bedding caves) are also frequent along bedding planes higher up within the cliffs. Available evidence shows that gently sloping or even flat surfaces at the base of the cliffs are of depositional rather than erosional origin (Fig. 3). These ramps evolve from rock-fall derived talus, through its further disintegration

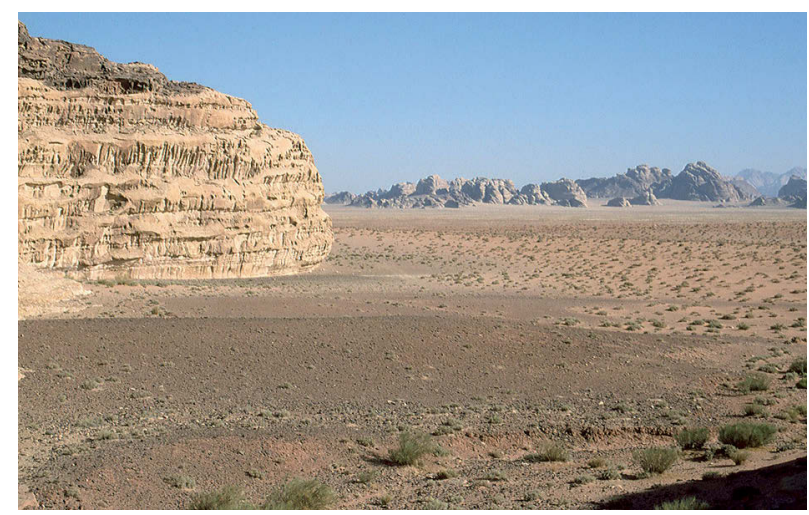

Fig. 3. Depositional ramps around inselbergs built of the Umm 'Ishrin Sandstone and redistribution by wind and water (Migon et al. 2005).

By contrast, a typical Disi Sandstone slope (Fig. 2c) consists of one or more upward curved segments, separated by major bedding planes. Extensive case hardening is largely unknown. Perhaps the most striking feature is the scarcity of coarse talus around Disi hills, and the absence of talus-derived depositional ramps. Instead, steep curved slopes are usually in direct contact with a sandy desert floor of aeolian origin. The summit part is usually convex in shape. Domelike morphology is not exclusively restricted to the Disi Sandstone unit. It also characterises insets of white sandstone within the Umm 'Ishrin Sandstone, although given the limited thickness of these insets, the white 'Ishrin hills are low (up to $30-40 \mathrm{~m}$ high) or there are no individual hills at all but localised convex segments within an otherwise vertical slope.

\section{Rock slope failures and patterns of slope evolution}

Gravity-driven mass movements are the dominant processes shaping rock slopes in the sandstone terrain of south-west Jordan. Their ubiquity has been pointed out by Osborn and Duford (1981) and further explored by Goudie et al. (2002), who noticed the presence of many generations of rock falls. However, the pattern of rock failures varies between the different sandstone units and accounts for contrasting pathways of rock slope evolution, hypothesized in Figure 4.

Umm 'Ishrin slopes fail in a number of ways, differing in size and type. Field evidence suggests that the following are present in the area: planar slides along steeply inclined failure planes, wedge slides, toppling, sagging of large columns of rock, and overhang collapse. Locally, failures affected the entire height of slope, up to $150 \mathrm{~m}$, and were as much as $200 \mathrm{~m}$ wide (Fig. 5). Although a complete inventory of rock failures across the region is yet to be made, a study carried out in the inselberg terrain around Al-Quwayra revealed a very high density of debris piles below the rock slopes, genetically linked to different types of rock failures. Along the perimeter of 


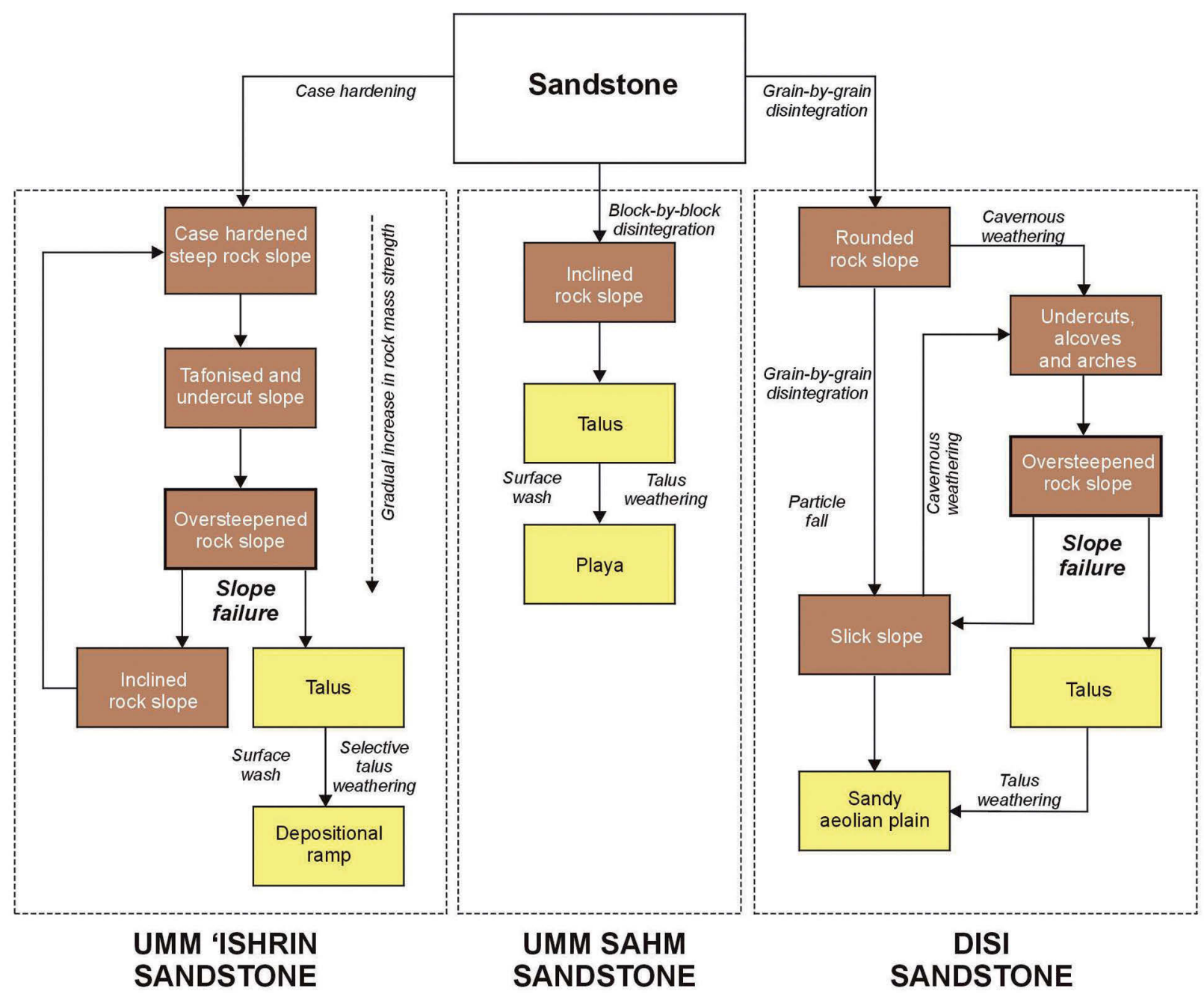

Fig. 4. Different pathways of slope evolution in the three major sandstone units of south-west Jordan (modified from Migon 2007)

five clusters of sandstone inselbergs Goudie et al. ern shoulder of the Dead Sea rift), but at present (2002; Fig. 5) mapped as many as 75 rock falls of various ages, as suggested by the state of weathering of rock fall debris. In the most extreme example of Jabal al Mu'ays the evidence of 21 rock slope failures is present along the perimeter of approximately $12 \mathrm{~km}$.

It seems that case hardening, a typical phenomenon in the Umm 'Ishrin Sandstone, is a significant factor in mass movement processes. It contributes to the increase in rock mass strength and allows the slopes to attain considerable steepness, while also enabling for an extensive development of cavernous weathering and slope undercutting along various discontinuities. This in turn acts towards increasing tensile stress, especially at the slope base, leading eventually to failure. Seismic triggers of some rock falls cannot be excluded (see Matmon et al., 2005, for the westthere is no solid supporting evidence. Debris accumulation due to slope failure occurs either away from the rock face or buries the slope/pied-

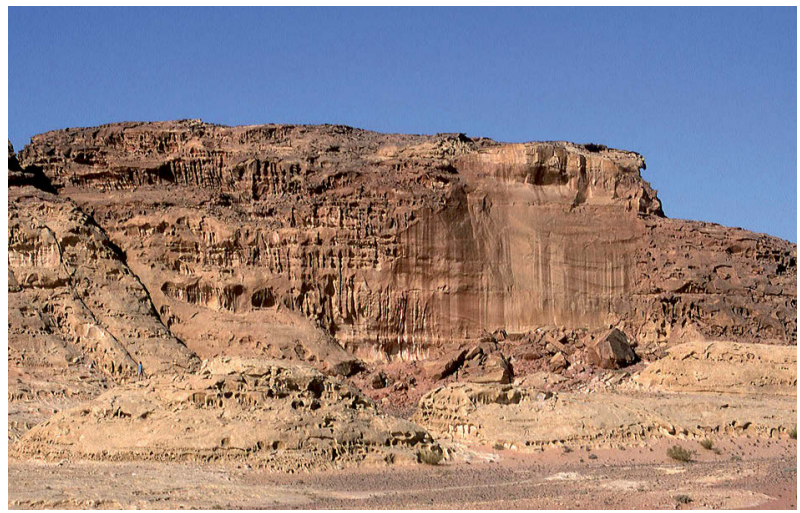

Fig. 5. Massive rock slope failure within the Umm 'Ishrin Sandstone. Note the smooth surface of the exposed failure plane, with no cavernous weathering present 
mont junction, depending on the failure type, but in any case rock fall debris disintegrates quickly due to the very efficient salt weathering (Goudie et al. 2002). In addition, many sandstone blocks split upon impact. The newly exposed failure plane is subject to a new cycle of case hardening, cavern development, slope steepening and failure. Over time, sandstone rock slopes retreat, the size of inselbergs diminishes, whereas their spacing increases.

The pathways of slope development in the Disi Sandstone are different and major rock failures are relatively infrequent. The absence of case hardening and poor development of cavernous weathering are very important, and oversteepened slopes prone to massive instantaneous collapse are rare. Instead, grain-by-grain disintegration plays an important part and the slopes lose mass at a relatively constant rate. This in turn leads to the development of curved, smooth slopes which decrease their gradient over time. Thus, whereas the Umm 'Ishrin slopes tend to retreat, their counterparts in the Disi Sandstone become also lowered and maintain their strength-equilibrium.

\section{Conclusion}

The sandstone landscape of south-west Jordan, including the world famous Wadi Rum and its vicinity, represents an outstanding example of desert sandstone geomorphology, of huge scientific importance and aesthetic significance. It offers an opportunity to examine a range of geomorphological problems such as the relationships between lithology, structure and landforms, temporal and spatial patterns of mass movements, pathways of slope development, controls on different weathering processes and others. It is a type area for the study of biofilms on sandstone surfaces (Viles, Goudie 2004) and the development of footslope ramps (Migon et al. 2005). As yet, poorly explored issues include the development and destruction of sandstone karst and the impact of environmental change in the Quaternary on the long-term evolution of landforms.

Although specific in detail, the sandstone landscape of south-west Jordan shares certain of its process and form characteristics with other desert landscapes of the world, such as those present in central Sahara (e.g. Tassili n' Ajjer, Tadrart Acacus) or the south-west United States (e.g. Monument Valley). Comparison with sandstone landscapes in humid environments, whether subtropical or temperate, including the sandstone tablelands of Central Europe and Danxia landscapes of southern China, is more difficult. In terms of processes at work, important differences may reside in weathering patterns, the significance of fluvial processes and erosional dissection, rates of geomorphic change over time, and interactions between geomorphic processes and vegetation (see Härtel et al. 2007, Young et al. 2009). However, some geomorphic features of sandstone terrain are present in both arid and humid environments and these include steep curved rock slopes, sapping cirques, massive horizontal overhangs, and slot canyons. It remains to be determined whether their universal occurrence indicates a common origin, or we are dealing with classic examples of landform convergence, in which very different processes acting in dissimilar environments lead to the same end-result.

\section{References}

Abdelhamid G., 1990. The geology of the Jabal Umm Ishrin area (Wadi Rum). Bulletin, Geology Directorate, Amman 14.

Abu-Safat M., 1987. Verwitterung and Hangabtragung im "Nubischen Sandstein" Südjordaniens. Mitteilungen der Fränkischen Geographischen Gesellschaft 33/34: 129-256.

Adamovič J., Mikuláš R., Cílek V., 2006. Sandstone Districts of the Bohemian Paradise: Emergence of a Romantic Landscape. Geolines 21: 1-100.

Amireh, B.S., 1994. Heavy and clay minerals as tools in solving stratigraphic problems; a case study from the Disi Sandstone (Early Ordovician) and the Kurnub Sandstone (Early Cretaceous) of Jordan. Neues Jahrbuch für Geologie und Paläontologie, Monatshefte 4: 205-222.

Debossens G., 2000. Rock bridges of the Wadi Rum desert. In: The Natural Arch and Bridge Society website; http:// www.naturalarches.org/span-0004-WadiRum.htm [access date: 01-07-2014]

Goudie A., Migon P., Allison R.J., Rosser N., 2002. Sandstone geomorphology of the Al Quwayra area of south Jordan. Zeitschrift für Geomorphologie N. F. 46: 365-390.

Grimes K., Wray R., Spate A., Houshold I., 2008. Karst and Pseudokarst in Northern Australia. Report on the field study of June-August 2008. Department of the Environment, Water, Heritage and the Arts, Australia.

Grab S.W., Goudie A.S., Viles H.A., Webb N., 2011. Sandstone geomorphology of the Golden Gate Highlands Na- 
tional Park, South Africa in a global context. Koedoe 53: $1-14$.

Härtel H., Cílek V., Herben T., Jackson A., Williams R. (eds). Sandstone Landscapes. Academia, Praha, $496 \mathrm{pp}$.

Huang Jin, 2009, Preliminary study on Danxia landform in China. In: First International Symposium on Danxia Landform. World Danxia. The 1st Collection. Danxiashan, Guangdong, China, 2009.05.26-28: 132-146.

Kasprzak M., Migoń P., 2014. DEM-based analysis of geomorphology of a stepped sandstone plateau, Stołowe Mountains (SW Poland). Zeitschrift für Geomorphologie N. F. (in print).

Makhlouf I.M., Abed A.M., 1991. Depositional facies and environments in the Umm Ishrin Sandstone Formation, Dead Sea area, Jordan. Sedimentary Geology 71: 177-187.

Matmon A., Shaked Y., Porat N., Enzel Y., Finkel R., Lifton N., Boaretto E., Agnon A., 2005. Landscape development in an hyper arid sandstone environment along the margins of the Dead Sea fault: implications from dated rock falls. Earth and Planetary Science Letters 240: 803-817.

Migoń P., 2007, Rozwój urwisk skalnych w środowisku pustynnym południowej Jordanii (Evolution of precipitous rock slopes in the desert environment of southern Jordan). In: Smolska E., Giriat D. (red.), Rekonstrukcja dynamiki procesów geomorfologicznych - formy rzeźby $i$ osady. Uniwersytet Warszawski, Wydział Geografii i Studiów Regionalnych - Komitet Badań Czwartorzędu PAN, Warszawa: 313-323.

Migoń P., Goudie A., Allison R.J., Rosser N., 2005. The origin and evolution of footslope ramps in the sandstone desert environment of south-west Jordan. Journal of Arid Environments 60: 303-320.
Osborn G., 1985. Evolution of Late Cenozoic inselberg landscape of southwestern Jordan. Palaeogeography, Palaeoclimatology, Palaeoecology 49: 1-23.

Osborn G., Duford J. M., 1981. Geomorphological processes in the inselberg region of south-western Jordan. Palestine Exploration Quarterly 1981: 1-17.

Peng Hua, 2000, Danxia Geomorphology of China and Its Progress in Research Work. Zhongshan University, Guangzhou.

Rabba I., 1991. The geology of the Al Quwayra area. Bulletin, Geology Directorate, Amman, 16.

Rast H., 1959. Geologischer Führer durch das Elbsandsteingebirge. Bergakademie, Freiberg.

Robinson D.A., Williams R.B.G., 1994. Sandstone weathering and landforms in Britain and Europe. In: Robinson D.A., Williams R.B.G. (eds), Rock Weathering and Landform Evolution. Wiley, Chichester, 371-391.

Selley, R.C., 1972. Diagnosis of marine and non-marine environments from the Cambro-Ordovician sandstones of Jordan. Journal of Geological Society London 128: 135-150.

Viles H.A., Goudie A.S., 2004. Biofilms and case hardening on sandstones from Al-Quwayra, Jordan. Earth Surface Processes and Landforms 29: 1473-1486.

Young, R.W., 1987. Sandstone landforms of the tropical East Kimberley Region, Northwestern Australia. Journal of Geology 95: 205-218.

Young R.W., Wray R.A.L., Young A.R.M., 2009. Sandstone Landforms. Cambridge University Press, Cambridge.

Zhao Xun, 2009. Discussion on Danxia landform. In: First International Symposium on Danxia Landform. World Danxia. The 1st Collection. Danxiashan, Guangdong, China, 2009.05.26-28: 53-120. 